\title{
Front Matter: Volume 7078
}

, "Front Matter: Volume 7078," Proc. SPIE 7078, Developments in X-Ray Tomography VI, 707801 (7 October 2008); doi: 10.1117/12.812653

SPIE Event: Optical Engineering + Applications, 2008, San Diego, California, United SPIE. States 


\title{
PROCEEDINGS OF SPIE
}

\section{Developments in X-Ray Tomography VI}

\author{
Stuart R. Stock \\ Editor \\ 12-14 August 2008 \\ San Diego, California, USA \\ Sponsored and Published by \\ SPIE
}

Volume 7078 
The papers included in this volume were part of the technical conference cited on the cover and title page. Papers were selected and subject to review by the editors and conference program committee. Some conference presentations may not be available for publication. The papers published in these proceedings reflect the work and thoughts of the authors and are published herein as submitted. The publisher is not responsible for the validity of the information or for any outcomes resulting from reliance thereon.

Please use the following format to cite material from this book:

Author(s), "Title of Paper," in Developments in X-Ray Tomography VI, edited by Stuart R. Stock, Proceedings of SPIE Vol. 7078 (SPIE, Bellingham, WA, 2008) Article CID Number.

ISSN 0277-786X

ISBN 9780819472984

Published by

SPIE

P.O. Box 10, Bellingham, Washington 98227-0010 USA

Telephone +1 3606763290 (Pacific Time) · Fax +1 3606471445

SPIE.org

Copyright (C 2008, Society of Photo-Optical Instrumentation Engineers

Copying of material in this book for internal or personal use, or for the internal or personal use of specific clients, beyond the fair use provisions granted by the U.S. Copyright Law is authorized by SPIE subject to payment of copying fees. The Transactional Reporting Service base fee for this volume is $\$ 18.00$ per article (or portion thereof), which should be paid directly to the Copyright Clearance Center (CCC), 222 Rosewood Drive, Danvers, MA 01923. Payment may also be made electronically through CCC Online at copyright.com. Other copying for republication, resale, advertising or promotion, or any form of systematic or multiple reproduction of any material in this book is prohibited except with permission in writing from the publisher. The CCC fee code is $0277-786 \mathrm{X} / 08 / \$ 18.00$.

Printed in the United States of America.

Publication of record for individual papers is online in the SPIE Digital Library.

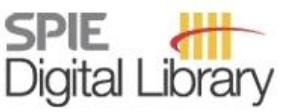

SPIEDigitallibrary.org

Paper Numbering: Proceedings of SPIE follow an e-First publication model, with papers published first online and then in print and on CD-ROM. Papers are published as they are submitted and meet publication criteria. A unique, consistent, permanent citation identifier (CID) number is assigned to each article at the time of the first publication. Utilization of CIDs allows articles to be fully citable as soon they are published online, and connects the same identifier to all online, print, and electronic versions of the publication. SPIE uses a six-digit CID article numbering system in which:

- The first four digits correspond to the SPIE volume number.

- The last two digits indicate publication order within the volume using a Base 36 numbering system employing both numerals and letters. These two-number sets start with 00, 01, 02, 03, 04, 05, $06,07,08,09,0 A, 0 B \ldots 0 Z$, followed by $10-12,20-2 Z$, etc.

The CID number appears on each page of the manuscript. The complete citation is used on the first page, and an abbreviated version on subsequent pages. Numbers in the index correspond to the last two digits of the six-digit CID number. 


\title{
Contents
}

\author{
xi Conference Committee \\ xiii Introduction
}

\section{SESSION 1 THE THIRD DECADE}

$707802 \quad X$-ray imaging: past and present (Invited Paper) [7078-01]

U. Bonse, Technical Univ. Dortmund (Germany)

707803 X-ray microtomography: past and present (Invited Paper) [7078-02]

J. C. Elliott, G. R. Davis, Queen Mary Univ. of London (United Kingdom); S. D. Dover, Dover Software Ltd. (United Kingdom)

707804 Trends in the micro- and nano-CT literature [7078-03]

S. R. Stock, Northwestern Univ. (United States)

707806 Whole-body imaging of whole-organ, subresolution, basic functional unit (BFU) perfusion characteristics (Invited Paper) [7078-05]

Y. Dong, E. L. Ritman, Mayo Clinic College of Medicine (United States)

\section{SESSION 2 LIFE SCIENCES I}

707807 Principle and applications of dual source CT (Invited Paper) [7078-06]

T. Flohr, Siemens Healthcare (Germany)

707808 Dynamic volume CT: the next revolution in clinical CT (Invited Paper) [7078-07]

K. Boedeker, R. Mather, Toshiba America Medical Systems, Inc. (United States)

707809 Four-dimensional time-resolved micro-CT imaging for small animals [7078-08]

X. Liu, F. Nadeem, P. L. Salmon, A. Sasov, SkyScan N.V. (Belgium)

7078 OA Use of synchrotron tomography to image naturalistic anatomy in insects [7078-09]

J. J. Socha, F. De Carlo, Argonne National Lab. (United States)

\section{SESSION 3 LIFE SCIENCES II}

$7078 \mathrm{OB} \quad$ High-resolution tomographic imaging of microvessels (Invited Paper) [7078-10]

B. Müller, S. Lang, Univ. Basel (Switzerland); M. Dominietto, M. Rudin, ETH Zürich (Switzerland);

G. Schulz, H. Deyhle, M. Germann, Univ. Basel (Switzerland); F. Pfeiffer, Paul Scherrer Institut

(Switzerland) and EPF Lausanne (Switzerland); C. David, Paul Scherrer Institute (Switzerland);

T. Weitkamp, European Synchrotron Radiation Facility (France) 
7078 OC Comparative micro computed tomography study of a vertebral body [7078-11]

S. Drews, Univ. Basel (Switzerland) and Kantonsspital Bruderholz (Switzerland); F. Beckmann, J. Herzen, GKSS-Research Ctr. Geesthacht (Germany); O. Brunke, phoenix|x-ray Systems + Services GmbH (Germany); P. Salmon, Skyscan N.V. (Belgium); S. Friess, Gloor Instruments AG (Switzerland); A. Laib, B. Koller, Scanco Medical AG (Switzerland); T. Hemberger, phoenix |x-ray Systems + Services GmbH (Germany); M. Müller-Gerbl, B. Müller, Univ. Basel (Switzerland)

7078 OD Applying x-ray tomography in the field of vertebrate biology: form, function, and evolution of the skull of caecilians (Lissamphibia: Gymnophiona) [7078-12]

T. Kleinteich, Univ. Hamburg (Germany); F. Beckmann, J. Herzen, GKSS-Research Ctr. Geesthacht (Germany); A. P. Summers, Univ. of California, Irvine (United States); A. Haas, Univ. Hamburg (Germany)

$7078 \mathrm{OE} \quad$ A comparison of three different micro-tomography systems for accurate determination of microvascular parameters (Invited Paper) [7078-13]

P. D. Lee, R. C. Atwood, P. Rockett, Imperial College London (United Kingdom);

M. A. Konerding, Johannes Gutenberg Univ., Mainz (Germany); J. R. Jones, Imperial College London (United Kingdom); C. A. Mitchell, Univ. of Ulster (United Kingdom)

\section{SESSION $4 \quad$ ALGORITHMS}

7078 OF Interior tomography: theory, algorithms, and applications (Invited Paper) [7078-14] H. Yu, Virginia Polytechnic Institute and State Univ. (United States); Y. Ye, Univ. of lowa (United States); G. Wang, Virginia Polytechnic Institute and State Univ. (United States)

7078 OG The discrete Radon transform: a more efficient approach to image reconstruction? [7078-15] A. Kingston, The Australian National Univ. (Australia); I. Svalbe, Monash Univ. (Australia); J.-P. Guédon, IRCCyN-IVC, École Polytech., I'Univ. de Nantes (France)

7078 Ol Investigation of helix-saddle trajectories for cone-beam CT [7078-17]

Y. LU, J. Zhao, Shanghai Jiao Tong Univ. (China); E. Bai, The Univ. of Iowa (United States); G. Wang, Virginia Polytechnic Institute and State Univ. (United States)

$70780 \mathrm{~J}$ Determination of the exact reconstruction region in the cone-beam composite-circling mode [7078-18]

L. Ye, lowa City West High School (United States); H. Yu, G. Wang, Virginia Polytechnic Institute and State Univ. (United States)

7078 OK Exact image reconstruction for triple-source cone-beam CT along saddle trajectories (Invited Paper) [7078-19]

Y. Lu, J. Zhao, Shanghai Jiao Tong Univ. (China); G. Wang, Virginia Polytechnic Institute and State Univ. (United States)

\section{SESSION $5 \quad$ LIFE SCIENCES III}

$7078 \mathrm{OL} \quad$ Visualizing the root-PDL-bone interface using high-resolution micro-tomography [7078-20] M. Dalstra, P. M. Cattaneo, Åarhus Univ. (Denmark); J. Herzen, F. Beckmann, GKSS-Research Ctr. Geesthacht (Germany) 
7078 OM Synchrotron radiation-based micro computed tomography in the assessment of dentin deand re-mineralization [7078-21]

F. Kernen, T. Waltimo, H. Deyhle, Univ. of Basel (Switzerland); F. Beckmann, GKSS-Research Ctr. Geesthacht (Germany); W. Stark, ETH Zürich (Switzerland); B. Müller, Univ. of Basel (Switzerland)

7078 ON Quality assessment of clinical computed tomography [7078-22]

D. Berndt, M. Luckow, J. T. Lambrecht, Univ. of Basel (Switzerland); F. Beckmann, GKSS-Research Ctr. Geesthacht (Germany); B. Müller, Univ. of Basel (Switzerland)

\section{SESSION 6 TECHNICAL ADVANCES}

7078 OP MIRRORCLE light source demonstrating one micron resolution and clear density mapping (Invited Paper) [7078-24]

H. Yamada, T. Hiraia, Ritsumeikan Univ. (Japan); M. Morita, D. Hasegawa, M. Hanashima, Photon Production Lab. Ltd. (Japan)

$70780 Q \quad$ Novel sampling strategies for $x$-ray fluorescence computed tomography [7078-25] P. J. La Rivière, P. Vargas, The Univ. of Chicago (United States)

7078 OR A compact MicroCT/MicroXRF scanner for nondestructive 3D chemical analysis [7078-26] A. Sasov, X. Liu, D. Rushmer, SkyScan N.V. (Belgium)

7078 OS Region of interest reconstruction in x-ray fluorescence computed tomography [7078-27] P. J. La Rivière, P. Vargas, D. Xia, X. Pan, The Univ. of Chicago (United States)

7078 OT Comparative study of desktop- and synchrotron radiation-based micro computed tomography analyzing cell-seeded scaffolds in tissue engineering of bone [7078-28] A. Papadimitropoulos, Univ. Hospital Basel (Switzerland); S. Friess, Gloor Instruments AG (Switzerland); F. Beckmann, GKSS-Research Ctr. Geesthacht (Germany); P. Salmon, SkyScan N.V. (Belgium); S. Riboldi, Univ. Hospital Basel (Switzerland); D. Hutmacher, Queensland Univ. of Technology (Australia); I. Martin, Univ. Hospital Basel (Switzerland); B. Müller, Univ. of Basel (Switzerland)

7078 OU Comparison between $x$-ray tube-based and synchrotron radiation-based $\mu \mathrm{CT}$ [7078-29] O. Brunke, phoenix |x-ray Systems + Services GmbH (Germany); K. Brockdorf, phoenix |x-ray Systems + Services, Inc. (United States); S. Drews, B. Müller, Univ. of Basel (Switzerland); T. Donath, J. Herzen, F. Beckmann, GKSS-Research Ctr. Geesthacht (Germany)

\section{SESSION 7 SYNCHROTRON RADIATION}

7078 OV Hierarchical multimodal tomographic x-ray imaging at a superbend [7078-30]

M. Stampanoni, Paul Scherrer Institut (Switzerland) and ETH Zürich (Switzerland)); F. Marone, G. Mikuljan, Paul Scherrer Institut (Switzerland); K. Jefimovs, P. Trtik, Swiss Federal Labs. for Material Testing and Research (Switzerland); J. Vila-Comamala, C. David, R. Abela, Paul Scherrer Institut (Switzerland) 
7078 OX The high-resolution synchrotron-based imaging stations at the BAMline (BESSY) and TopoTomo (ANKA) [7078-32]

A. Rack, Forschungszentrum Karlsruhe GmbH (Germany); H. Riesemeier, Federal Institute for Materials Research and Testing (Germany); S. Zabler, Max-Planck-Institute of Colloids and Interfaces (Germany); T. Weitkamp, Forschungszentrum Karlsruhe GmbH (Germany) and European Synchrotron Radiation Facility (France); B. R. Müller, G. Weidemann, Federal Institute for Materials Research and Testing (Germany); P. Modregger, Forschungszentrum Karlsruhe GmbH (Germany); J. Banhart, Hahn-Meitner-Institut Berlin GmbH (Germany); L. Helfen, Forschungszentrum Karlsruhe GmbH (Germany); A. N. Danilewsky, Albert-Ludwigs-Univ. Freiburg (Germany); H. G. Gräber, Rheinisch Westfälische Technische Hochschule (Germany); R. Heldele, Forschungszentrum Karlsruhe GmbH (Germany); B. Mayzel, Tel Aviv Univ. (Israel); J. Goebbels, Federal Institute for Materials Research and Testing (Germany); T. Baumbach, Forschungszentrum Karlsruhe GmbH (Germany)

$70780 Z$ The GKSS beamlines at PETRA III and DORIS III [7078-34]

A. Haibel, F. Beckmann, T. Dose, J. Herzen, S. Utcke, T. Lippmann, N. Schell, A. Schreyer, GKSS-Research Ctr. Geesthacht (Germany)

$707810 \quad X$-ray zoom-in tomography of calcified tissue [7078-35]

X. Xiao, F. De Carlo, Argonne National Lab. (United States); S. R. Stock, Northwestern Univ. (United States)

\section{SESSION $8 \quad$ PHASE IMAGING I}

707811 Sensitivity of x-ray phase tomography based on Talbot and Talbot-Lau interferometer (Invited Paper) [7078-36]

A. Momose, W. Yashiro, Y. Takeda, N. Maikusa, The Univ. of Tokyo (Japan)

707812 X-ray phase-contrast local tomography image reconstruction on pi-lines [7078-37] M. A. Anastasio, Illinois Institute of Technology (United States); D. Shi, Toshiba Medical Research Institute USA, Inc. (United States); X. Pan, The Univ. of Chicago (United States)

$707813 \quad$ Noise properties of in-line x-ray imaging and tomography [7078-38]

C.-Y. Chou, National Taiwan Univ. (Taiwan); M. A. Anastasio, Illinois Institute of Technology (United States)

707814 Quantitative investigation of phase retrieval from x-ray phase-contrast tomographic images [7078-39]

H. O. Moser, K. Banas, A. Chen, T. Vo Nghia, L. K. Jian, S. M. P. Kalaiselvi, G. Liu, S. M. Maniam, P. D. Gu, National Univ. of Singapore (Singapore); S. W. Wilkins, T. E. Gureyev, S. C. Mayo, CSIRO Manufacturing and Infrastructure Technology (Australia); M. Cholewa, Monash Univ. (Australia); Z. J. Li, Albert-Ludwigs-Univ. Freiburg (Germany) 
707815 Advances in the visualization of unstained brain tumors using grating-based $x$-ray phase-contrast tomography (Invited Paper) [7078-40]

F. Pfeiffer, Paul Scherrer Institut (Switzerland) and Ecole Polytechnique Fédérale de Lausanne (Switzerland); O. Bunk, C. David, Paul Scherrer Institut (Switzerland); M. Bech, Univ. of Copenhagen (Denmark); G. Le Duc, A. Bravin, P. Cloetens, European Synchrotron Radiation Facility (France)

707816 X-ray phase-contrast imaging with 2D grating interferometry (Invited Paper) [7078-41] M. Jiang, Peking Univ. (China) and Virginia Polytechnic Institute and State Univ. (United States); C. L. Wyatt, G. Wang, Virginia Polytechnic Institute and State Univ. (United States)

707817 Phase-contrast imaging and tomography at $60 \mathrm{keV}$ using a conventional x-ray tube [7078-42]

T. Donath, Paul Scherrer Institut (Switzerland); F. Pfeiffer, Paul Scherrer Institut (Switzerland) and Ecole Polytechnique Fédérale de Lausanne (Switzerland); O. Bunk, W. Groot, M. Bednarzik, C. Grünzweig, Paul Scherrer Institut (Switzerland); E. Hempel, S. Popescu, M. Hoheisel, Siemens AG (Germany); C. David, Paul Scherrer Institut (Switzerland)

707818 Development of ultrafast laser-based x-ray in-vivo phase-contrast micro-CT beamline for biomedical applications at Advanced Laser Light Source (ALLS) [7078-43]

R. Kincaid, Syracuse Univ. (United States); A. Krol, Syracuse Univ. (United States) and SUNY Upstate Medical Univ. (United States); S. Fourmaux, J.-C. Kieffer, C. Serbanescu, M. Servol, Univ. du Québec (Canada); L. Vogelsang, Syracuse Univ. (United States); S. Wilkins, A. Stevenson, Y. Nesterets, CSIRO Materials Science \& Engineering (Australia); E. Lipson, H. Ye, Syracuse Univ. (United States); A. Pogany, CSIRO Materials Science \& Engineering (Australia)

707819 Quantitative phase-contrast tomography using polychromatic radiation [7078-44] G. R. Myers, Monash Univ. (Australia); T. E. Gureyev, CSIRO Materials Science and Engineering (Australia); D. M. Paganin, Monash Univ. (Australia) and CSIRO Materials Science and Engineering (Australia); K. K. W. Siu, Monash Univ. (Australia); S. C. Mayo, S. W. Wilkins, CSIRO Materials Science and Engineering (Australia)

70781 A Validity of a fully coherent field model for in-line x-ray phase imaging [7078-45] A. M. Zysk, M. N. Wernick, M. A. Anastasio, Illinois Institute of Technology (United States)

\section{SESSION 10 METROLOGY I}

7078 1C Compensation of mechanical inaccuracies in micro-CT and nano-CT [7078-47] A. Sasov, X. Liu, P. L. Salmon, SkyScan N.V. (Belgium)

7078 1D High-density resolution in synchrotron-radiation-based attenuation-contrast microtomography (Invited Paper) [7078-48]

F. Beckmann, J. Herzen, A. Haibel, GKSS-Research Ctr. Geesthacht (Germany); B. Müller, Univ. of Basel (Switzerland); A. Schreyer, GKSS-Research Ctr. Geesthacht (Germany) 
7078 1E A modelling approach to beam hardening correction (Invited Paper) [7078-49]

G. Davis, Queen Mary Univ. of London (United Kingdom); N. Jain, Indian Institute of Technology Kanpur (India); J. Elliott, Queen Mary Univ. of London (United Kingdom)

7078 IG Metrology with $\mu \mathrm{CT}$ : precision challenge [7078-51]

A. Suppes, E. Neuser, phoenix |x-ray systems + services GmbH (Germany)

$7078 \mathrm{1H}$ The interior of soil aggregates investigated by synchrotron-radiation-based microtomography [7078-52]

S. Peth, R. Horn, Christian-Albrechts-Univ. Kiel (Germany); F. Beckmann, T. Donath, GKSS-Research Ctr. Geesthacht (Germany); A. J. M. Smucker, Michigan State Univ. (United States)

\section{SESSION 12 PHYSICAL SCIENCES, ENGINEERING}

707811 Three-dimensional analysis of $\mathrm{MMC}$ microstructure and deformation by $\mu \mathrm{CT}$ and FE simulations [7078-53]

H.-A. Crostack, TU Dortmund (Germany); J. Nellesen, G. Fischer, RIF e.V. (Germany);

U. Weber, S. Schmauder, Univ. of Stuttgart (Germany); F. Beckmann, GKSS-Research Ctr. Geesthacht (Germany)

$7078 \mathrm{lJ}$ Investigation of creep cavity coalescence in brass by in-situ synchrotron x-ray microtomography [7078-54]

A. Isaac, K. Dzieciol, F. Sket, Max-Planck-Institut für Eisenforschung GmbH (Germany); M. di Michiel, T. Buslaps, European Synchrotron Radiation Facility (France); A. Borbély, A. R. Pyzalla, Max-Planck-Institut für Eisenforschung GmbH (Germany)

$70781 \mathrm{M}$ In-situ $\mathrm{x}$-ray diffraction profiling of cracks and metal-metal interfaces at the nanoscale [7078-57]

A. Y. Nikulin, A. V. Darahanau, R. A. Dilanian, B. C. Muddle, Monash Univ. (Australia);

A. Y. Souvorov, O. Sakata, JASRI/SPring-8 (Japan)

\section{POSTER SESSION}

707810 Angiofil: a novel radio-contrast agent for post-mortem micro-angiography [7078-60] S. Grabherr, Univ. de Lausanne (Switzerland); M. Dominietto, ETH Zürich (Switzerland); L. YU, Toronto Ctr. for Phenogenomics (Canada); V. Djonov, Univ. Fribourg (Switzerland); B. Müller, Univ. Basel (Switzerland); S. Friess, Gloor Instruments AG (Switzerland)

$70781 \mathrm{P} \quad$ A system for high-resolution $\mathrm{x}$-ray phase-contrast imaging and tomography of biological specimens [7078-59]

L. Poletto, M. Caldon, G. Tondello, CNR - National Institute for the Physics of Matter (Italy) and Univ. degli Studi di Padova (Italy); A. Megighian, Univ. degli Studi di Padova (Italy)

$70781 Q \quad$ Adaptive acquisition geometry for micro-CT with large format detectors [7078-65] A. Sasov, F. Nadeem, X. Liu, K. Verelst, SkyScan (Belgium) 
7078 IR Optimization of pinhole cameras for emission tomographic systems [7078-70] A. Sasov, SkyScan (Belgium)

7078 is Coherent $x$-ray scattering for discriminating bio-compatible materials in tissue scaffolds [7078-71]

C. Cui, S. M. Jorgensen, D. R. Eaker, E. L. Ritman, Mayo Clinic College of Medicine (United States)

7078 IT MicroCT and microMRI imaging of a prenatal mouse model of increased brain size [7078-69] E. K. N. López, S. R. Stock, Northwestern Univ. (United States); M. M. Taketo, Kyoto Univ. (Japan); A. Chenn, Northwestern Univ. (United States); M. J. Ravosa, Univ. of Missouri, Columbia (United States)

$70781 \mathrm{U}$ Micro-computer tomography and a renaissance of insect morphology [7078-66] F. Friedrich, R. G. Beutel, Friedrich-Schiller-Univ. Jena (Germany)

7078 IV SR $\quad$ CT study of crack propagation within laser-welded aluminum-alloy T-joints [7078-68] J. Herzen, F. Beckmann, S. Riekehr, F. S. Bayraktar, A. Haibel, P. Staron, GKSS-Research Ctr. Geesthacht (Germany); T. Donath, GKSS-Research Ctr. Geesthacht (Germany) and Paul Scherrer Institut (Switzerland); S. Utcke, M. Kocak, A. Schreyer, GKSS-Research Ctr. Geesthacht (Germany)

7078 IW High-density resolution synchrotron radiation based x-ray microtomography (SR $\mu \mathrm{CT})$ for quantitative 3D-morphometrics in zoological sciences [7078-67]

M. Nickel, J. U. Hammel, Friedrich-Schiller-Univ. Jena (Germany); J. Herzen, GKSS-Research Ctr. Geesthacht (Germany); E. Bullinger, Univ. of Strathclyde (United Kingdom);

F. Beckmann, GKSS-Research Ctr. Geesthacht (Germany)

7078 1X Internal structures of scaffold-free 3D cell cultures visualized by synchrotron radiation-based micro-computed tomography [7078-72]

B. Saldamli, Johann Wolfgang Goethe-Univ. Frankfurt am Main (Germany) and Univ. Hospital Basel (Switzerland); J. Herzen, F. Beckmann, GKSS-Research Ctr. Geesthacht (Germany); J. Tübel, J. Schauwecker, R. Burgkart, Technische Univ. München (Germany); P. Jürgens, H.-F. Zeilhofer, Univ. Hospital Basel (Switzerland); R. Sader, Johann Wolfgang Goethe-Univ. Frankfurt am Main (Germany); B. Müller, Univ. Basel (Switzerland)

$707822 \quad \mathrm{X}$-ray tomographic microscopy at TOMCAT [7078-76]

F. Marone, C. Hintermüller, Paul Scherrer Institut (Switzerland); S. McDonald, Paul Scherrer Institut (Switzerland) and Univ. Lausanne (Switzerland); R. Abela, G. Mikuljan, A. Isenegger, Paul Scherrer Institut (Switzerland); M. Stampanoni, Paul Scherrer Institut (Switzerland) and ETH Zurich (Switzerland)

Author Index 
Downloaded From: https://www.spiedigitallibrary.org/conference-proceedings-of-spie on 26 Apr 2023

Terms of Use: https://www.spiedigitallibrary.org/terms-of-use 


\title{
Conference Committee
}

\author{
Program Track Chairs
}

Sandra G. Biedron, Argonne National Laboratory (United States) and Sincrotrone Trieste (Italy)

Massimo Altarelli, Deutsches Elektronen-Synchrotron (Germany)

Conference Chair

Stuart R. Stock, Northwestern University (United States)

Program Committee

Felix Beckmann, GKSS Research Center Geesthacht (Germany)

Graham R. Davis, Queen Mary University of London (United Kingdom)

Bert Müller, University of Basel (Switzerland)

Erik Leo Ritman, Mayo Clinic College of Medicine (United States)

Mark L. Rivers, The University of Chicago (United States)

Ge Wang, Virginia Polytechnic Institute and State University (United States)

Stephen W. Wilkins, Commonwealth Scientific and Industrial Research Organisation (Australia)

\section{Session Chairs}

1 The Third Decade

Stuart R. Stock, Northwestern University (United States)

2 Life Sciences I

Erik Leo Ritman, Mayo Clinic College of Medicine (United States)

3 Life Sciences II

Graham R. Davis, Queen Mary University of London (United Kingdom)

4 Algorithms

Ge Wang, Virginia Polytechnic Institute and State University (United States)

$5 \quad$ Life Sciences III

Bert Müller, University of Basel (Switzerland) 
6 Technical Advances

Stephen W. Wilkins, Commonwealth Scientific and Industrial Research Organisation (Australia)

7 Synchrotron Radiation

Felix Beckmann, GKSS Research Center Geesthacht (Germany)

$8 \quad$ Phase Imaging I

Stephen W. Wilkins, Commonwealth Scientific and Industrial Research Organisation (Australia)

9 Phase Imaging II

Felix Beckmann, GKSS Research Center Geesthacht (Germany)

10 Metrology I

Graham R. Davis, Queen Mary University of London (United Kingdom)

11 Metrology II

Erik Leo Ritman, Mayo Clinic College of Medicine (United States)

12 Physical Sciences, Engineering

Bert Müller, University of Basel (Switzerland) 


\section{Introduction}

The sixth conference in this series was marked by a change in the conference chair. Professor Ulrich Bonse, who had chaired the first five meetings, was honored by SPIE for his hard work. In this, the fourth decade of Computed Tomography and the third decade of Micro-Computed Tomography in this series, several talks covered the development of x-ray imaging, the very early days of micro-tomography, and trends in the literature. There was a strong thread throughout of advancing capabilities in clinical instruments, in research instrumentation for laboratory and synchrotron x-ray sources, and in improved reconstruction algorithms.

The diversity of applications underlined the mature interdisciplinary scope of the conference. Established groups continued the trend of more detailed and sophisticated analyses than in previous meeting, and new contributors (both early career and senior investigators) brought fresh ideas to the meeting.

I would like to thank the authors for their excellent contributions, and the program committee for their very important help. Last, but not least, the SPIE staff provided exemplary support with the program development, the meeting itself, and the proceedings.

Stuart R. Stock

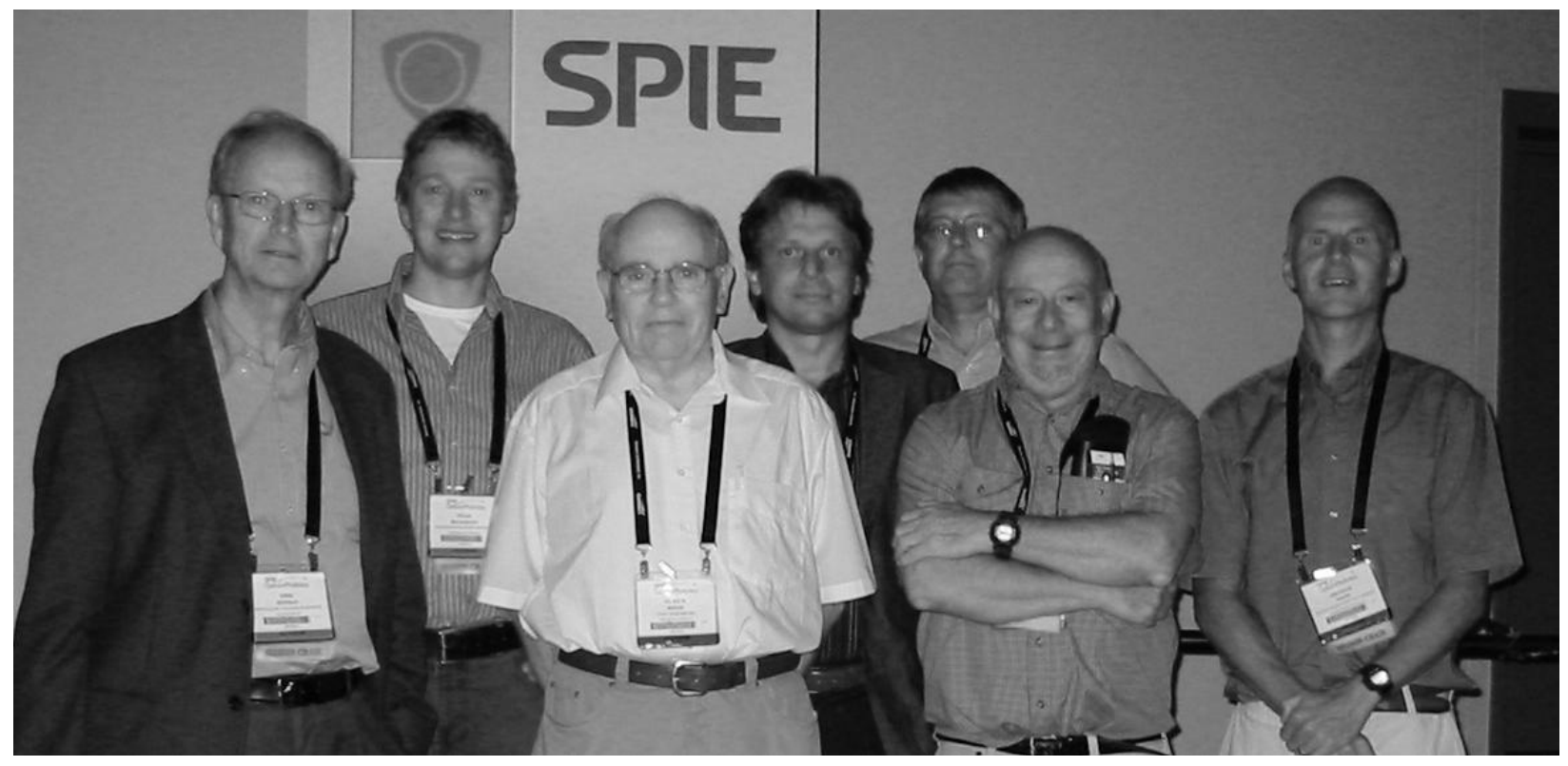

The program committee at the close of the conference. From the left: Erik Ritman, Felix Beckmann, Ulrich Bonse, Bert Müller, Stuart Stock, Steve Wilkins and Graham Davis. 
Downloaded From: https://www.spiedigitallibrary.org/conference-proceedings-of-spie on 26 Apr 2023

Terms of Use: https://www.spiedigitallibrary.org/terms-of-use 